\title{
Cap a una pràctica de projectes orientats a la modelització
}

\author{
Neus Garriga $\bowtie$, Teresa Pigrau i Neus Sanmartí \\ Centre de Documentació i Experimentació en Ciències (CDEC) i Universitat Autònoma de Barcelona
}

Molt bona part dels projectes de ciències que s'apliquen a les aules d'infantil i primària tenen com a eix l'aprofundiment en alguna temàtica científica. En aquest article analitzem com han evolucionat els projectes realitzats per una de les autores, de manera que el treball fet s'orienti a promoure processos de modelització del coneixement científic en els infants.

Paraules clau: projectes, modelització, conversa, competències

\section{Introducció}

Treballar per projectes (Hernández y Ventura, 1992; Martín, 2006) a les escoles sol tenir la connotació d'utilitzar un bon procés d'ensenyament i aprenentatge; però hi ha moltes maneres de posarlos en pràctica i no totes les metodologies ajuden de la mateixa manera a fer evolucionar les idees dels infants ni potencien les mateixes competències.

N'hi ha que afavoreixen que el treball de la mainada es centri en copiar, retallar i enganxar informacions recollides a partir de la lectura de llibres o d'explicacions d'algun adult, però no conviden gaire a reflexionar sobre les pròpies idees ni a revisar-les i a ser autònoms aprenent. En moltes ocasions es centren més en satisfer curiositats, i no tant en aprendre a actuar de manera responsable en el seu entorn immediat.

D'altres comporten que els nens i nenes siguin molt experts en un determinat tema i en coneguin molts detalls, però que no construeixen coneixements potents que els possibilitin aplicar-los a l'anàlisi d'altres situacions o problemes, és a dir, a transferir els seus aprenentatges.

A partir del treball fet en el marc de la llicència d'estudis "Projectes per ajudar a evolucionar les idees científiques i les competències dels infants" (2009) concedida pel Departament d'Educació, s'ha analitzat com han evolucionat els projectes aplicats per la primera firmant a l'etapa d'educació infantil i als primers cursos de primària, des d'uns projectes que en podríem dir "tradicionals", fins els actuals que volen potenciar processos de modelització de coneixements clau, transferibles, tot desenvolupant de manera harmònica les diferents competències. Diferents exemples d'aquest projectes es poden trobar al bloc:

\section{http://blocs.xtec.cat/projectesdeciencies/}

Els aspectes que es podrien analitzar de les diferents pràctiques són molt diversos, perquè tota pràctica d'aula és complexa i hi intervenen molts factors. Però en aquest escrit reflexionarem especialment a l'entorn de:

- L'elecció, presentació i seqüència de realització del projecte

- La gestió de les converses

- Les principals característiques dels projectes orientats a la modelització

- Les competències treballades

\section{L'elecció, presentació i seqüència de realització del projecte}

És indubtable que la manera com s'escull o defineix el tema del projecte, com es concreten els continguts i la metodologia de treball, i com es seqüencia el procés de realització, influeix en els resultats d'aprenentatge. En aquest apartat es reflexiona sobre aquests aspectes, a partir d'analitzar 
característiques de diferents tipus de projectes aplicats habitualment a les nostres escoles, alguns dels quals formen part de la nostra pràctica educativa.

\section{1.a) Projectes escollits únicament pels infants sense tenir en compte si el tema escollit permet treballar aspectes significatius del coneixement}

Hem pogut comprovar que en algunes ocasions, quan no hi ha una bona gestió per part del professorat, els temes escollits pels infants solen ser temàtiques llunyanes i poc experimentals, que els desperten una curiositat inicial per saber sobre el tema (sovint condicionat per allò que es parla a través dels mitjans), però que no possibiliten que es pugui interaccionar ni experimentar amb el fet o fenomen objecte d'estudi. Això comporta que, en la majoria dels casos, aviat s'esgoti la motivació inicial i que costi mantenir-la per poder arribar a elaborar la producció final esperada -que acostuma a ser un dossier o un àlbum-.

Els temes més freqüents que es solen triar són els relacionats amb els dinosaures, egipcis, lleons, dofins, pirates, indis..., i per avançar en l'adquisició de coneixements entorn d'ells, gairebé l'única metodologia que es fa servir es relaciona amb cercar informació en mitjans externs o escoltar la que els proporciona un expert. Sobre aquests temes, és difícil observar directament, recollir dades i comprovar si les pròpies idees són coherents amb les observacions. També és difícil que comportin reflexionar sobre les maneres d'actuar responsablement en el nostre context. Tot i així és cert que de vegades es poden trobar camins tant per experimentar, com per desenvolupar valors i, no cal dir, construir coneixements significatius.

En molts casos la proposta de treball que ofereixen els projectes passa per la seqüència, més o menys mecanitzada, que comença plantejant les preguntes següents:

- Què saben?

- Què volen saber?

- Com poden trobar la informació?

i es continua a partir de:

- Construir un índex amb les preguntes que s'han plantejat

- Buscar la informació per trobar les respostes a les preguntes

- Resumir què s'ha après del tema

- Fer un dossier
Quan es realitzen aquests projectes, generalment el professorat no s'ha plantejat cap objectiu concret pel que fa a tot el procés d'aprenentatge en relació al tema escollit. Únicament es treballen les preguntes que els infants han mostrat interès per conèixer, que gairebé sempre són del mateix tipus. Aquestes qüestions, en la majoria dels casos, es responen simplement buscant informació; impliquen poques activitats experimentals i sovint la mainada ja sap la resposta o la intueix quan ha plantejat la pregunta, o bé estan molt lluny de les seves possibilitats de comprensió. Els coneixements 'apresos' no es relacionen amb cap model teòric que després es pugui transferir per comprendre altres fets o temàtiques similars, i generalment no s'arriben a treballar tots els elements necessaris per entendre'l i incorporar-lo a l'explicació dels fets.

En aquest tipus de projectes podríem dir que el contingut és el menys important, i en canvi es potencia la capacitat competencial de negociar i pactar la temàtica objecte d'estudi, i sovint la de trobar i organitzar la informació.

No cal dir que hi ha mestres que són capaços de reconduir les preguntes dels nens i nenes i treballar de manera significativa tot tipus de sabers a partir de les temàtiques escollides. Tanmateix cal ser capaç d'aprofundir en les possibilitats d'aprenentatge que ofereix el tema $\mathrm{i}$ en les formes d'aconseguir que la mainada les construeixi a partir de les activitats de tots tipus que es puguin promoure.

\section{1.b) Projectes escollits pel professorat sense tenir presents els interessos de l'alumnat o la rellevància en el seu context}

És el cas d'aplicar projectes que ofereixen les editorials o que es troben a Internet. Normalment està tot previst i es concreten en un conjunt de fitxes preparades. Cada any es fa el mateix, sigui quines siguin les característiques i interessos del grup classe.

El procés d'ensenyament i aprenentatge no es gestiona a partir de les idees que tenen els infants, donat que està ben marcat el camí que s'ha de seguir per al seu "desenvolupament". Sovint es redueix a copiar informacions que ja es donen o a realitzar activitats molt rutinàries.

L'aprenentatge es relaciona fonamentalment amb "nomenar i memoritzar" fets, objectes, éssers vius, les seves parts, les funcions... i es connecta poc amb la vida dels infants i amb una actuació responsable, més enllà de donar i repetir unes quantes normes. 
1.c) Projectes proposats més o menys directament pel professorat tenint en compte tant els interessos dels infants com les possibilitats que ofereixen per treballar models teòrics significatius

En els darrers cursos ens hem decantat per plantejar els projectes des d'aquest punt de vista.

A l'hora d'escollir el tema del projecte partim del fet que interaccionem constantment amb objectes, éssers vius, materials... i observem fets i fenòmens quotidians. Aquestes vivències ens poden portar a parlar-ne, plantejar-nos preguntes, interrogants $i$, finalment, decidir voler emprendre l'aventura de conèixer-los amb més profunditat, tot observant-los amb una altra mirada, experimentant, buscant noves dades... Però també serà important que el tema sigui rellevant socialment, és a dir, que pugui portar a aprofundir en les nostres actuacions i valors.

Un altre aspecte a tenir en compte és si el tema escollit permet fomentar l'interès dels nens i les nenes una vegada hagi minvat la seva curiositat inicial, per tal de seguir aprofundint-lo tot generant noves mirades i plantejant nous interrogants.

En són exemples:

- Escollim el tema dels éssers vius del jardí de l'escola perquè ens hem trobat amb formigues, aranyes, centpeus... i ha sorgit l'interès del grup per conèixer, observar i experimentar com són, com viuen, com és nodreixen, com és relacionen i com és reprodueixen. També valorem que el tema ens permet relacionar-lo amb actuacions, com per exemple: està ben fet matar-los quan els trobem?

El tema ens permet iniciar-lo construint un terrari a la classe, que possibilita realitzar, a l'entorn seu, diferents activitats d'observació, d'experimentació i comunicació.

- Algun infant porta la seva mascota a classe i a partir d'aquest fet decidim criar pollets, conills o altres animals, per tenir la nostra pròpia mascota a l'escola. Aquest fet ens possibilita pensar en com tenir-ne cura.

Per saber i justificar com atendre'ls en les millors condicions, ens cal analitzar i tenir present què necessiten per viure $i$, per tant, aprofundir en el model escolar d'ésser viu. Si ja han construït una primera idea del model, l'ampliem concretant alguna de les funcions i reconeixent la diversitat de maneres de fer-les.

- Són les festes de Sant Medir o de Sant Antoni i recollim multitud de caramels $i$ ens sorgeix el dubte de què fer-ne. Podem aprofitar la il.lusió que els fa tenir-los per treballar tota una sèrie de coneixements, ja siguin matemàtics (com estimar o comptar quants en tenim i com distribuirlos per les classes), ja siguin de ciències (de què estan fets? com els fan? per què ens produeixen les càries? com i per què tenir cura de les dents?...)

És a partir de tots aquests interrogants que sorgeix la necessitat de realitzar el projecte, que porta a l'aprenentatge de coneixements transferibles relacionats amb la matemàtica, amb l'estudi de la matèria i els seus canvis o sobre com els bacteris fan les funcions pròpies dels éssers vius. També podem aprofundir en com es redacta un text descriptiu o un d'explicatiu.

- Quan juguen amb les seves joguines o amb els jocs fixos del parc, o quan utilitzen altres màquines senzilles de l'escola i de casa, es plantegen preguntes sobre com funcionen, què les fa funcionar, què passa quan funcionen, com estan fetes, quines diferències hi ha entre les joguines d'ara i les dels avis?... i podem aprofitar aquesta avinentesa per plantejar un projecte que doni resposta als seus dubtes i interrogants, tot aprenent a construir les seves pròpies joguines o màquines i a utilitzar-les responsablement.

La raó de plantejar aquestes situacions d'aprenentatge, amb preguntes relacionades amb actuacions o problemes a resoldre, és ajudar els infants a fer-se "bones" preguntes i prediccions, que es puguin investigar, deduir-ne conclusions i abstreure regularitats o idees potents per continuar aprenent. Hem comprovat que aquest plantejament estimula la seva motivació, el seu interès i creativitat durant tot el procés de realització del projecte, i alhora potencia el desenvolupament de tot tipus de competències.

També els porta a fer-se cada vegada més preguntes interessants sobre els fets i fenòmens que els envolten, perquè les situacions que es treballen són significatives per a ells i elles, i també per a l'aprenentatge de coneixements transferibles i rellevants socialment; és a dir, comporten repensar actuacions entorn a aspectes ambientals, de salut, tecnològics i, en general, de ciutadania.

Hem pogut comprovar que després d'haver treballat tot el que necessiten els conills o altres animals per viure (és a dir, per fer les funcions comunes a tots els éssers vius), els infants són capaços de transferir aquests coneixements a altres situacions per explicar-les i fer-se noves preguntes. Per exemple, explicar com es produeixen les càries al menjar caramels i com prevenir-les (els bacteris es 
nodreixen a partir de sucres i produeixen com a residus àcids que ataquen l'esmalt de les dents), o en funció de saber que tot el que és viu respira, preguntar-se com respiren un pollet dins de l'ou i el tronc d'un arbre.

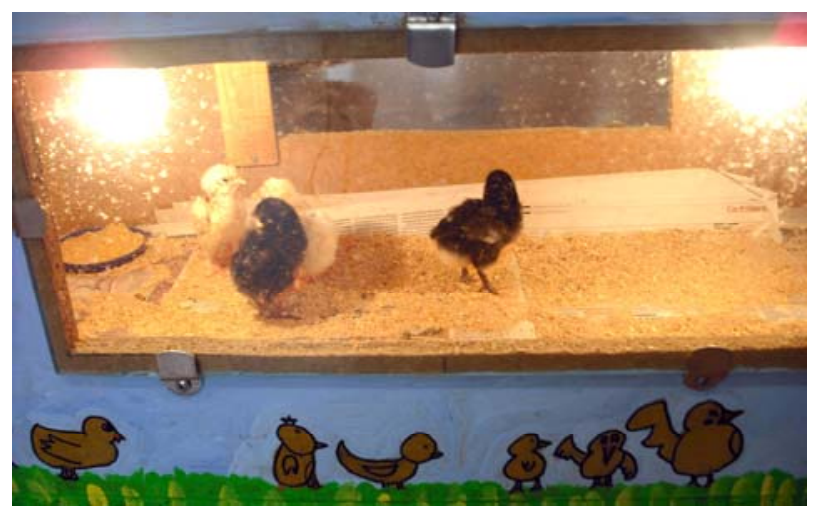

El projecte es presenta a la mainada partint d'un escenari concret -veure l'animal a classe, portar joguines després de reis, una visita a una granja, participar en la recollida de caramels al barri...- per crear un marc comú d'objectius i de principis compartits. Des de l'inici es promou una avaluació dialogant, per fer els nens i nenes partícips de la tasca i protagonistes del seu procés d'aprenentatge.

Un cop consensuat el tema d'estudi, com a mestres ens plantegem uns objectius inicials en funció de les competències que volem ajudar a desenvolupar, relacionant els coneixements, procediments, actituds i valors implicats que considerem bàsics i significatius des del camp de saber de referència.

Treballem de manera que una àrea de coneixement $\mathrm{i}$, en concret, un model teòric específic $\mathrm{i}$ global (en el nostre cas, del camp de les ciències) sigui el que guia la seqüència d'activitats, i segons les necessitats de coneixements per resoldre el problema o per fonamentar l'actuació es treballen altres camps del saber (llenguatge, matemàtiques, ciències socials, plàstica, les TAC...)

Aquests objectius no són estàtics al llarg del projecte. A partir de les experiències que viu l'alumnat i de les preguntes que va formulant, es modifiquen i se'n van generant de nous. Constantment s'incorporen noves reflexions i experimentacions. Per tant, concebem el tema de manera oberta, flexible i dinàmica, per tal que permeti incorporar nous interessos, reptes i tots aquells aspectes que poden sorgir al treballar els fets i fenòmens des de la seva complexitat. És també important saber-lo tancar un cop s'han assolit els aprenentatges consensuats, sense eternitzar-lo.
Valorem que aquesta manera de treballar els projectes té en compte les idees i propostes dels infants i permet anar construint cada dia una experiència única i singular, avançar en la construcció dels aprenentatges i viure situacions inoblidables. Les idees de les que es parlen i les situacions que es viuen provoquen que aflorin emocions i sentiments positius en relació a què i com s'aprèn, tant en l'alumnat com en el professorat, segurament fruit del fet que reconeixen que són capaços d'utilitzar autònomament idees complexes i maneres de fer a l'hora de comprendre fets, de fer prediccions i d'actuar.

\section{2) La gestió de les converses}

Una de les activitats bàsiques en la realització de projectes és la conversa en gran grup. La manera com es gestioni determinarà els resultats que se n'obtinguin (Márquez i Pujol, 2005). Normalment l'objectiu és que aflorin i es verbalitzin idees a partir de les preguntes que interessa respondre, de les respostes inicials que es donen o bé de les propostes sobre què fer i com. A través de la conversa, es contrasten punts de vista, s'analitzen i valoren, s'arriba a consensos i, per tant, s'estimula la autoregulació.

En aquest apartat presentem les conclusions obtingudes de l'estudi realitzat sobre dues maneres diferents de gestionar una conversa. Aquesta anàlisi s'ha fet a partir de les converses de diversos grups de P-5, tal com les fèiem uns anys enrere (situació A) i tal com les promovem en l'actualitat (situació B).

Hem analitzat diverses converses de cada una de les tipologies i les idees que manifesten els nens i nenes en funció del model escolar que es treballa, per poder-les comparar i treure'n conclusions. En aquest escrit comparem els exemples de dos projectes: un de titulat "Els dofins" i un altre anomenat "Volem criar pollets".

\section{2.a) Anàlisi de la tipologia de converses corresponents a una situació A}

En la metodologia aplicada en aquesta situació, el professorat, quan inicia el projecte, pregunta als infants què saben del tema en qüestió. Seguidament els demana què volen saber i, quan s'ha acabat el projecte, els pregunta què han après. Entremig pot ser que es faci alguna altra conversa sobre algun tema específic, per revisar alguna idea o posar en comú alguna informació recollida. 
El quadre 1 recull les respostes d'un grup-classe sobre què saben dels dofins.

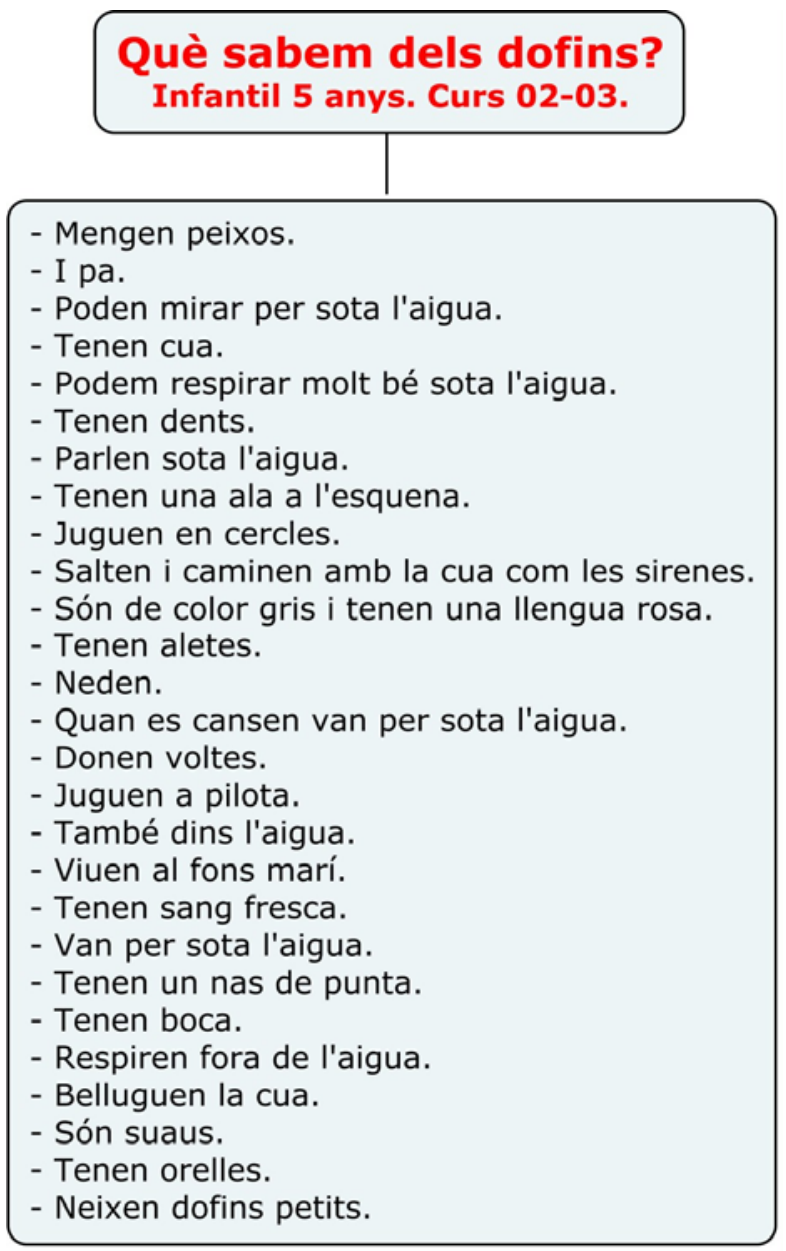

Quadre 1. Respostes dels infants a la pregunta "què en sabem de...?"

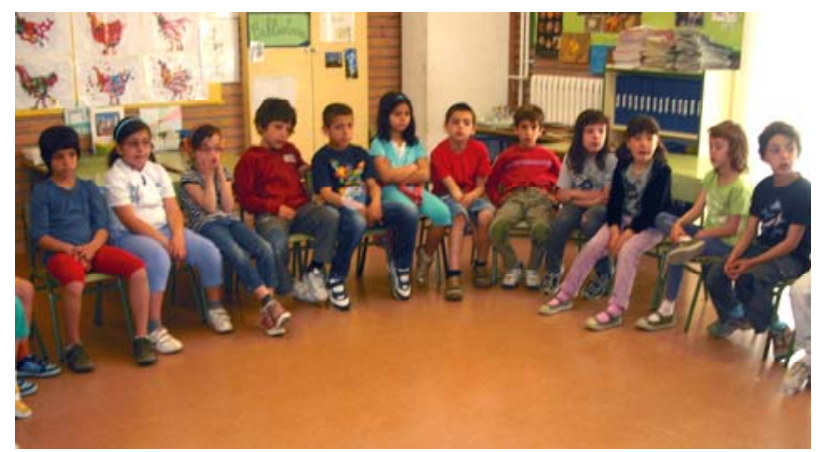

Hem comprovat que la pregunta "Què sabeu de...?", és molt general, poc significativa i poc productiva. En aquest moment els infants encara no s'han formulat cap qüestió i el que fan es intentar recordar què han llegit o vist a la $\mathrm{TV}$, però el que diuen no orienta a pensar sobre què es necessita saber o saber fer per resoldre un problema que tingui sentit per a ells, ni orienta a pensar en el model d'ésser viu, en la seva complexitat.

Sense crear un escenari motivador que orienti l'alumnat i que l'engresqui a participar, aquest tipus de conversa no potencia l'expressió dels seus models explicatius i l'establiment de relacions amb les seves experiències, ni l'ajuda a focalitzar la reflexió sobre allò que serà rellevant d'aprendre. El centre de la conversa és el tema objecte d'estudi i no tant la mainada ni com són els seus esquemes cognitius, ni les seves actuacions.

Posteriorment, sovint també sense partir de cap context experiencial significatiu o problema, se'ls demana que facin preguntes sobre què volen saber del tema que han proposat treballar. L'objectiu que es percep al fer les preguntes és recollir informació per respondre-les (què mengen? com són els fills? on viuen?...) Gairebé sempre són poc investigables experimentalment (si no es recondueixen). Normalment les obtenen preguntant als adults o consultant llibres, sense contrastar-les amb les seves idees inicials, ni amb observacions i dades que puguin recollir.

La interacció que es produeix en aquest tipus de conversa entre el professorat i l'alumnat és unidireccional. Quan el professorat fa la pregunta "Què sabeu de...?, els nens i nenes diuen el que creuen conèixer dirigint-se únicament a ell.

Aquesta tipologia de conversa no reflecteix una situació normal de comunicació i no potència poder discrepar, debatre ni aprofundir sobre les idees que s'expressen, fet que propicia que els infants, en moltes de les ocasions, no s'escoltin els uns als altres per avorriment i manca d'interès.

La finalitat d'aquestes converses és únicament exploratòria i serveixen al professorat per comparar les idees inicials i finals de la mainada respecte del fet o fenomen en estudi. En molts dels projectes, tot i que en aquestes converses es recullen les idees alternatives, poques vegades es gestionen per poder-les utilitzar per construir coneixement al llarg del procés d'ensenyament i aprenentatge.

Sovint, l'educador no té per finalitat que els infants reformulin tant les preguntes com les idees que han expressat inicialment. Si aprenen, ho fan individualment a partir de reproduir allò que escolten dels adults (mestres i familiars) i que es dóna com a cert.

La posició del docent és força passiva: és un receptor que escolta el que s'expressa i pot o no anotar les idees que es van dient; no intervé gaire amb preguntes ni gestiona les respostes, és a dir, deixa el protagonisme als infants. La informació que el professorat rep de la conversa no és del tot 
fiable, perquè al ser una única pregunta inicial, no acostumen a sorgir qüestions que els preocupin perquè en dubtin o no ho sàpiguen, sinó que més aviat tendeixen a reproduir el que han vist o escoltat.

Les converses analitzades ens demostren que la mainada pot repetir la mateixa idea o expressarne de contradictòries i, en principi, ningú no ho gestiona. La majoria de vegades no es posen de manifest les possibles incongruències, esperant fer-ho posteriorment, fet que provoca que algun infant pugui aprendre, en un principi, el concepte equivocat i després li és més difícil rectificar-lo. També ens hem adonat que pocs nens i nenes aporten punts de vista interessants. Creiem que pot ser per l'ambigüitat de la pregunta o per la manca d'implicació.

Pel que fa a les idees expressades, analitzant i comparant les que es diuen a les diferents conver- ses, inicials i finals, ens adonem que n'expressen poques i que no han evolucionat gaire en relació a aspectes importants del model científic que s'està treballant. En canvi, sí que amplien molt les informacions i detalls de la vida de l'ésser viu estudiat (en aquest cas). També es constata que alguns conceptes erronis bàsics es segueixen expressant després d'haver realitzat el projecte.

Les respostes que donen són enumeratives, breus, superficials i reproductives de la informació recollida, i no es relacionen les unes amb les altres, ni amb el model teòric aplicable a la interpretació d'altres éssers vius.

És a dir, saben molt sobre els dofins però no aprenen a ser capaços de generalitzar. En les intervencions, tant a l'inici com al final, els infants utilitzen paraules o frases simples per enumerar o descriure els fets i fenòmens.

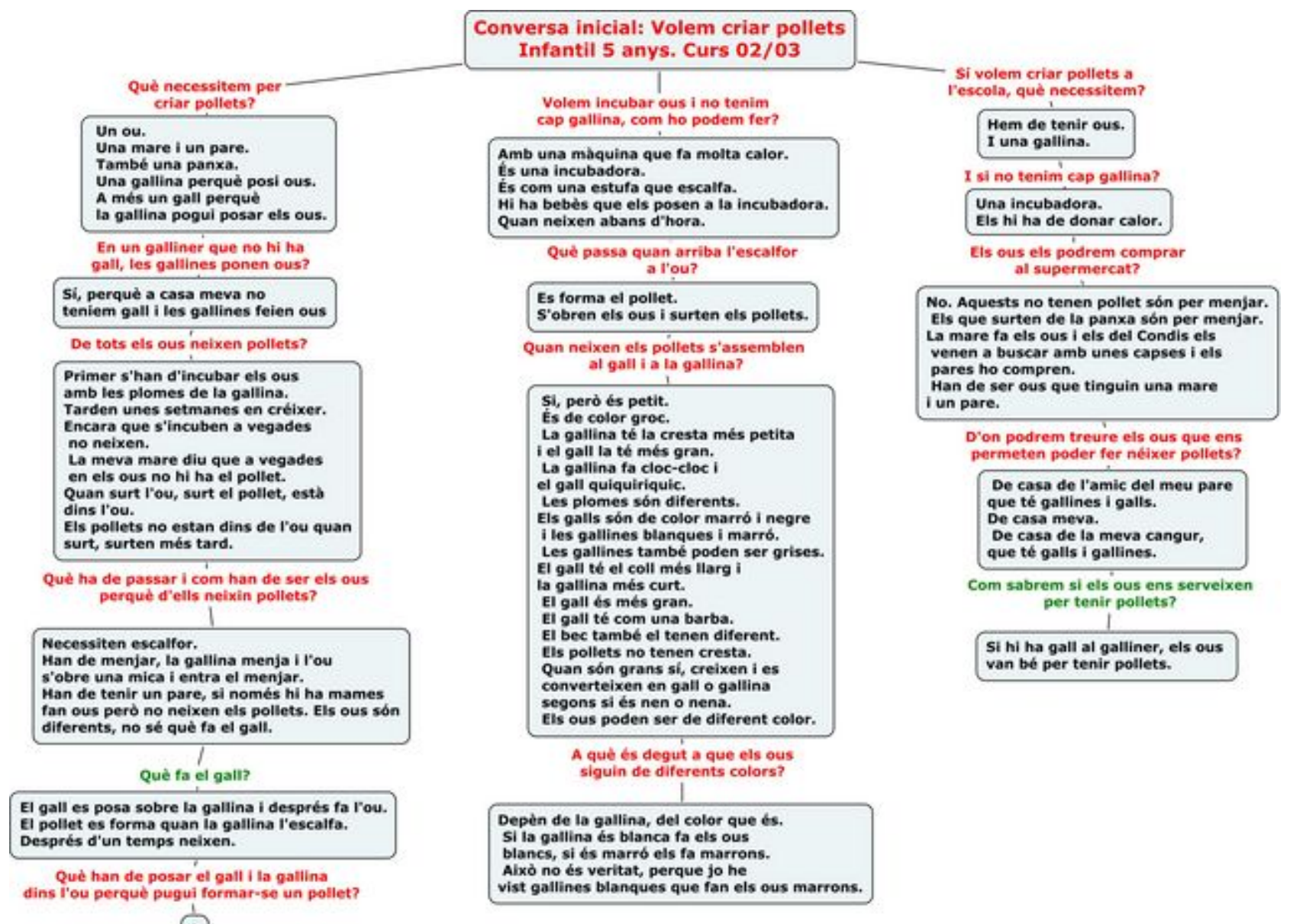

Quadre 2. Respostes dels infants durant la conversa inicial sobre la cria de pollets. 


\section{2.b) Anàlisi de la tipologia de converses corresponents a una situació $B$}

En la metodologia aplicada en aquest tipus de projectes, l'objectiu de la conversa inicial és, tal com s'ha dit, crear un escenari que motivi, emocioni i promogui l'interès per investigar i per aprendre. És a dir, no és tan important arribar a "saber" moltes coses, sinó a ser capaç d'utilitzar el que aprendran per actuar. De vegades ens ajudem de mediadors per iniciar aquesta conversa, tot presentant contes, joguines, algun ésser viu...

Es pretén que sigui significativa i funcional per a la mainada. Parlem del que necessitem per tirar endavant el projecte que tenim en comú: què podríem fer i què farem, què aprendrem... Tot això ajuda a crear un marc comú d'actuació per compartir objectius i expectatives i sentir-se parts integrants del projecte objecte d'estudi.

Les preguntes inicials busquen que els nens $i$ nenes puguin començar a pensar en funció del model teòric que es pretén ajudar a desenvolupar. Per tant les preguntes són més concretes que la general "què en sabeu de...?". Per exemple, el quadre 2 recull preguntes i respostes d'un grupclasse a l'inici d'un projecte sobre els pollets. L'acció que ens proposàvem era criar pollets a partir d'ous.

Cada vegada més, els projectes els presentem en forma de pregunta investigable, per tal de potenciar l'esperit d'indagació i comunicació: Per què es produeix càries al menjar caramels? Per què podem fer crispetes amb el blat de moro? Com hem de tenir cura dels llodrigons? Com funcionen les nostres joguines?...

De converses se'n fan constantment al llarg del projecte, sempre que sorgeix un problema o una pregunta que el docent considera interessant. Per tant, no es pretén conèixer totes les idees inicials de la mainada en la conversa inicial.

La finalitat de les diferents converses és que els infants vagin revisant les seves idees i propostes inicials en interacció amb els altres, tenint en compte les observacions que puguin anar fent. El que es diu es pot debatre, criticar i aprofundir, tot plantejant preguntes més detallades, que possibilitin mirar els fets des de punts de vista diferents.

Normalment, abans de realitzar les converses, s'han realitzat activitats on els infants han pogut fer una reflexió personal sobre els que saben del tema en qüestió o sobre els seus dubtes. És a dir, abans de la discussió collectiva es promou una reflexió individual, cosa que afavoreix que tots els nens $\mathrm{i}$ nenes hi pensin. Aquestes converses es promouen en el transcurs de la realització del projecte, sem- pre dins d'un context significatiu per a la mainada: després d'una sortida, de realitzar un dibuix o maqueta, després de realitzar uns experiments i observacions, davant d'un fet inesperat...

La conversa final ens serveix per estructurar tots els aprenentatges que hem realitzat de manera conjunta i així sintetitzar i generalitzar els coneixements adquirits, per poder-los aplicar a altres situacions quotidianes.

Per tant, les converses en aquesta tipologia de projectes tenen més finalitats que la d'exploració de coneixements previs. També (i sobretot) serveixen per construir nous sabers, per estructurar i sintetitzar el més important que s'ha parlat i après, i també per aplicar i generalitzar els nous sabers en altres exemples i contextos.

La posició del docent en aquestes converses és activa. Fa les preguntes necessàries relacionades amb els seus objectius -que es relacionen amb els sabers associats al model o models teòrics que es vol ajudar a construir- però sempre en funció dels interessos i les respostes dels infants. Impulsa que sorgeixin diferents punts de vista, que es contrastin i valorin, que es reflexioni sobre la seva possible idoneïtat $i$ que es prengui consciència dels canvis introduïts.

La interacció que es produeix entre els diferents membres del grup classe durant les diferents converses és multidireccional, és a dir, tant el professorat com els infants fan preguntes i es responen. La mainada pot començar responent a preguntes del docent però se'ls anima a formular-ne i a respondre's mútuament.

Aquesta gestió de la conversa fa que l'alumnat s'escolti, estigui atent i no es repeteixin tant les idees. El docent intervé amb preguntes per ajudarlos a analitzar les contradiccions que s'exposen i a rectificar els continguts erronis manifestats en el moment que es presenten. Aquesta gestió dels errors es fa mitjançant noves preguntes per fer reflexionar els nens i nenes, i que puguin reconèixer la resposta que seria més acceptada des del punt de vista científic actual. S'hi arriba tant a través de contrastar amb els resultats i observacions fetes en activitats experimentals com amb noves informacions que s'aporten, tot consensuant el punt de vista del grup.

En aquesta tipologia de conversa participen molt més tots els infants, doncs es recullen els seus dubtes quan sorgeixen $i$, en tot cas, s'aconsegueix recuperar la seva atenció quan es planteja una pregunta que activa de nou el seu pensament.

Comparant les idees inicials i finals dels infants hem comprovat que han evolucionat molt més que utilitzant la metodologia que hem descrit en relació a la situació $\mathrm{A}$. Si bé al principi donen respostes 
descriptives, a poc a poc comencen a aportar petites argumentacions i justificacions dels fets i processos. Aquestes idees estan més relacionades les unes amb les altres, i utilitzen frases més llargues i complexes per explicar els fenòmens. Segurament es deu al fet que el docent orienta la conversa cap a discutir les diferents idees i procediments bàsics relacionats amb el model teòric de referència $a$ construir i promou que tot el que s'afirma es fonamenti en observacions o en idees consensuades.

\section{3) Principals característiques dels projectes orientats a la modelització}

El tipus de projecte que es defensa en aquest article es caracteritza per uns aspectes propis del procés d'ensenyament i aprenentatge aplicat. Els més rellevants són:

- Es promou la relació constant entre el pensar, el fer i el comunicar (Arcà et al., 1990; Izquierdo i Aliberas, 2004), de manera interrelacionada, i és l'eix que guia el treball que es proposa. Totes les activitats busquen que els infants contrastin les seves idees amb la seva experiència $i$ observacions, i que ho verbalitzin.

- És té en compte el cicle d'aprenentatge (Jorba i Caselles, 1996) a l'hora de seqüenciar les diferents activitats. Se'n proposen d'exploració, d'apropiació dels objectius, d'introducció de nous punts de vista, de síntesis i estructuració, i de generalització i aplicació.

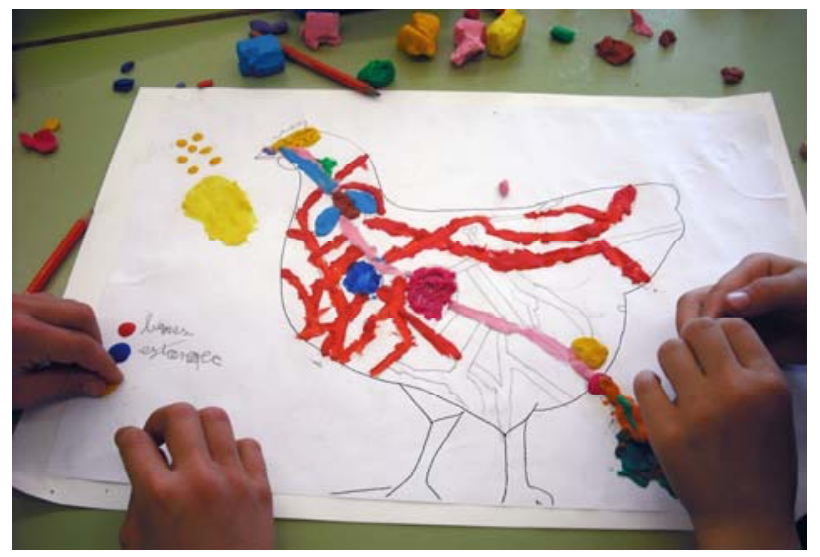

- S'introdueixen activitats de tipologia diversa, a fi que tot l'alumnat es senti implicat en funció del tipus d'intel-ligència que més domina (Gardner, 1984). Es busca afavorir l'emergència d'aptituds, preocupacions, interessos o idees, i que es comparteixin amb els companys. També es pretén que a través de les diferents activitats tots es sentint parts integrants del projecte que es té en comú, que s'hi comprometin i en siguin responsables.

- Són bàsiques les activitats d'investigació que requereixen l'observació, l'experimentació i la mesura, ja que es busca que les respostes es fonamentin en les proves obtingudes, diferenciant-les de les opinions personals.

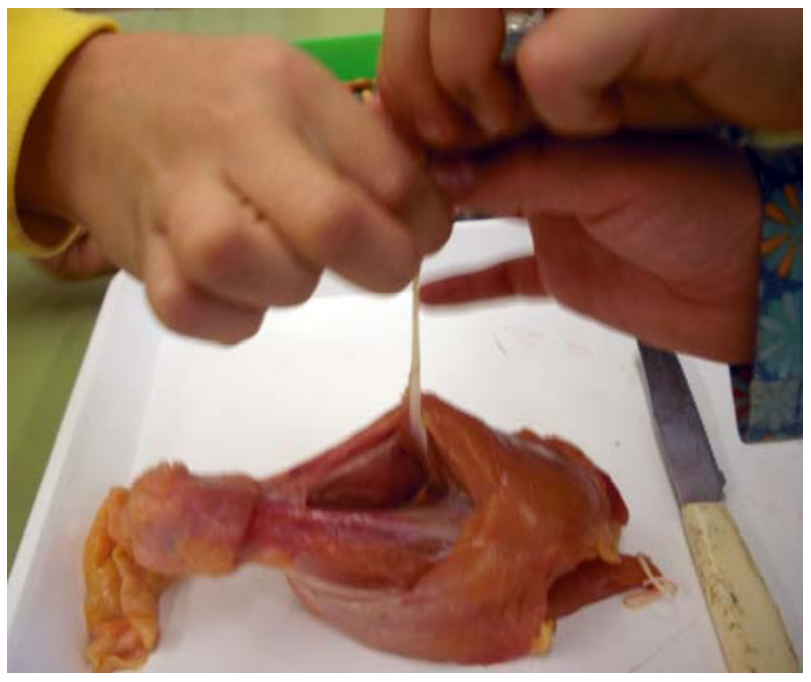

- Es propicia a totes les activitats que la mainada identifiqui les seves adquisicions i les seves mancances, és a dir, gestioni el seu propi aprenentatge a partir d'autoavaluar-se $\mathbf{i}$ autoregular-se (Sanmartí, 2007). Es coavaluen quan exposen les seves idees, les comparen amb les dels companys i companyes i fan propostes de millora. Això els ajuda a potenciar l'autonomia, la iniciativa $i$, en definitiva, a ser conscients de què aprenen i com ho fan per aprendre.

- Es potencia l'expressió de les idees en diferents llenguatges i modes comunicatius (oral, escrit, dibuix, maquetes, amb el propi cos...) (Pujol, 2003). Els infants pensen, imaginen i expressen primer les pròpies idees de manera individual, per després compartir-les i contrastar-les.

- S'estimula la reflexió a partir que els nens i nenes facin preguntes i prediccions investigables (Roca, 2005) i contrastin les idees pròpies amb les dels companys i companyes i amb les observacions fetes, tot analitzant similituds i diferències. La finalitat és provocar que formulin dubtes que els portin a la reflexió i al raonament (Martí, 2006). En aquesta línia l'actuació de la mestra és el model a partir del qual l'alumnat aprèn també a plantejar-se bones preguntes i a pensar en la qualitat de les respostes emeses. 
- S'ajuda a relacionar els nous coneixements amb les experiències prèvies dels infants que tenen relació amb la seva vida. Al tenir en compte la multiculturalitat que hi ha a les nostres aules s'aconsegueix que les temàtiques analitzades s'enriqueixin gràcies a la diversitat de cultures i vivències aportades.

- S'utilitzen diferents fonts i recursos ben variats, així com instruments, eines o materials, tant els d'ús quotidià com els de laboratori o els de l'hort o les sortides. Durant el desenvolupament del projecte també es potencia fer ús de les noves tecnologies per recollir dades d'observacions i experimentacions (sensors), per buscar informació i com a mitjà per comunicar els nous coneixements.

- S'estimula l'aplicació (transferència) dels models teòrics treballats $i$, en general, dels diferents sabers, en la interpretació de problemes o fets diferents i en la presa de decisions per actuar (Sanmartí, Burgoa i Nuño, 2011). Per tant, la finalitat no és tant saber moltes informacions atomitzades o puntuals, sinó de ser capaç de mobilitzar els diferents aprenentatges, de forma interrelacionada, per fonamentar actuacions (ser competent).

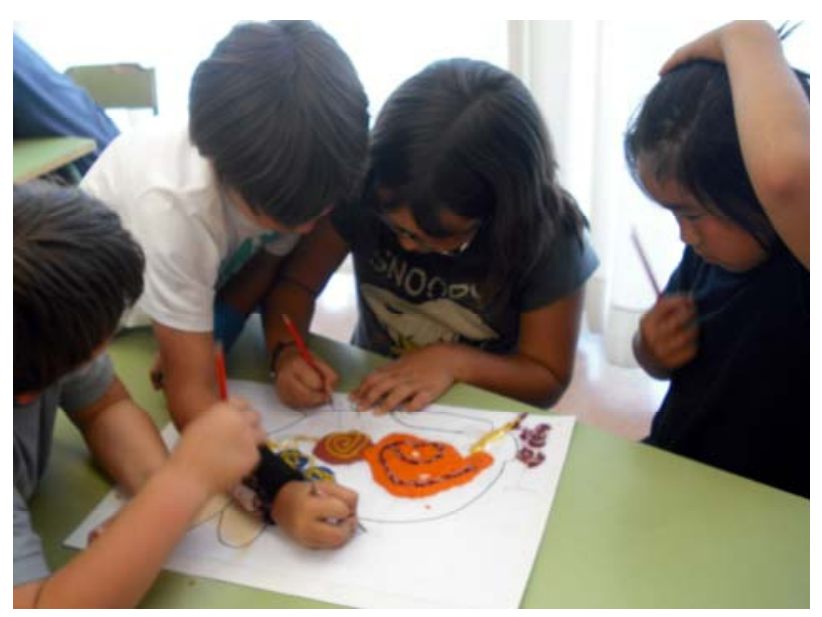

- Es promou una gestió d'aula que complementi el treball individual amb el col-lectiu (parelles, grups cooperatius i grup classe). Es vivencien els valors de l'autonomia, la solidaritat, l'ajuda mútua, l'empatia, la resolució de conflictes... Es propicien moments perquè es puguin expressar els coneixements, els procediments, els valors, els sentiments, les emocions i les normes de convivència que es van adquirint.
- Es busca respectar la diversitat de nivells de l'alumnat i que tots puguin avançar amb un ritme d'aprenentatge propi. Totes les idees i aportacions són valorades i es tenen en compte. Els resultats finals seran diferents però tots han d'avançar des del seu punt de partida, i no es deixa d'estimular a tots i cadascun dels alumnes.

- S'afavoreix el treball de valors i processos científics com són l'interès per preguntar-se, la imaginació, fer prediccions, buscar evidències, experimentar, mesurar, analitzar, treure conclusions i comunicar-les.

- Es treballen diferents habilitats de pensament, com recordar, comprendre, aplicar, analitzar críticament, avaluar o crear, incidint especialment en les d'ordre superior i no tant en recordar termes o repetir el que han llegit o sentit.

\section{4) Reflexions finals: competències treballades}

A partir de l'anàlisi que s'ha fet de l'evolució dels projectes que hem aplicat en aquests darrers anys, hem comprovat que els que estan enfocats a la modelització potencien un aprenentatge més competencial en els infants.

Si agafem com a referència els grans tipus de competències definides en el document DeSeCo (2002) de la Unió Europea, podem comprovar que aquestes es treballen de manera eficaç. En concret:

a) La competència de ser capaç de "d'utilitzar eines de manera interactiva i eficaç" (els diferents llenguatges i símbols per comunicar-nos, el coneixement i la informació, i les diferents tecnologies per a la informació i la comunicació) és bàsica en aquest tipus de projectes:

o En primer $\mathrm{lloc}_{\mathrm{o}}$ perquè els alumnes han de construir uns coneixements (models teòrics) que els són útils no només per saber sobre el tema del projecte, sinó per a d'altres en què es poden aplicar.

o En segon Iloc, perquè parteixen de plantejar-se preguntes investigables -i, per tant, les respostes són obertes- arribar-hi exigeix observar i experimentar i no només consultar informacions. Per això, els sabers els van construint de manera gradual. 


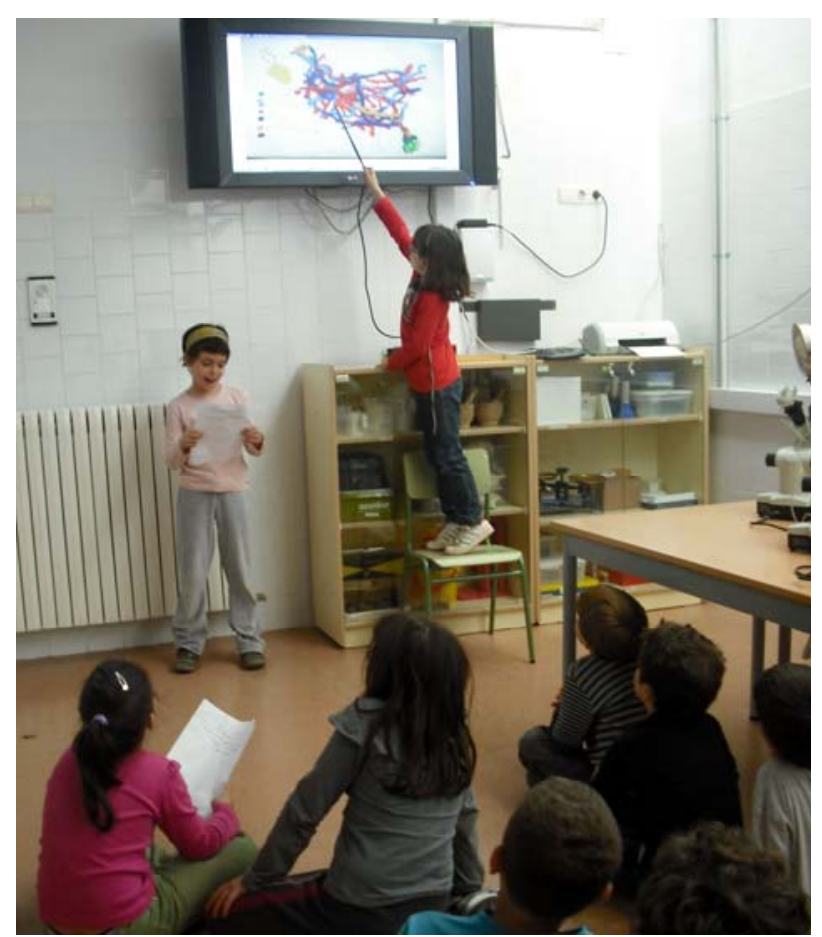

o I en tercer lloc, perquè en aquesta construcció és fonamental l'ús de diferents llenguatges -escrit, oral, dibuix, gestual, gràfic, matemàtic...- $i$ de diferents eines per expressar les idees, contrastar-les, resumir-les... -maquetes, blogs, powerpoints...-.

b) La competència de ser capaç de "funcionar en grups socials heterogenis", també és bàsica, ja que l'alumnat constantment ha d'interaccionar per contrastar, revisar i millorar les seves aportacions i produccions:

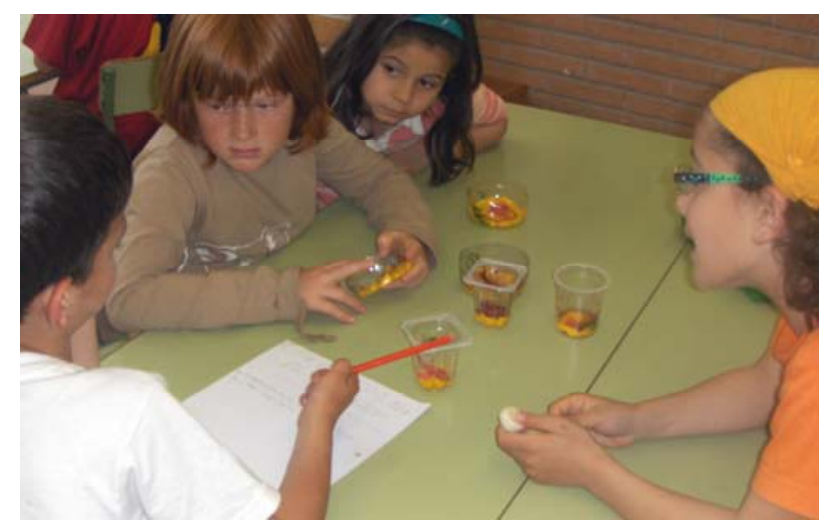

o En concret, tot el treball es fonamenta en estimular les interaccions entre els infants procurant fer adquirir el gust per escoltar i comprendre què diuen i fan els companys, i per resoldre amb empatia els possibles conflictes que sorgeixen.
- Això comporta acceptar com una font de riquesa la diversitat que hi ha a qualsevol grup. La regla que guia el treball és que tothom té alguna cosa per aportar i tots podem aprendre dels altres.

c) La competència de ser capaç "d'actuar de manera autònoma", és un altre dels eixos d'aquest tipus de projectes. Es promou que els alumnes prenguin decisions amb criteris propis a l'escollir com actuar en cada context, assumint-hi responsabilitats.

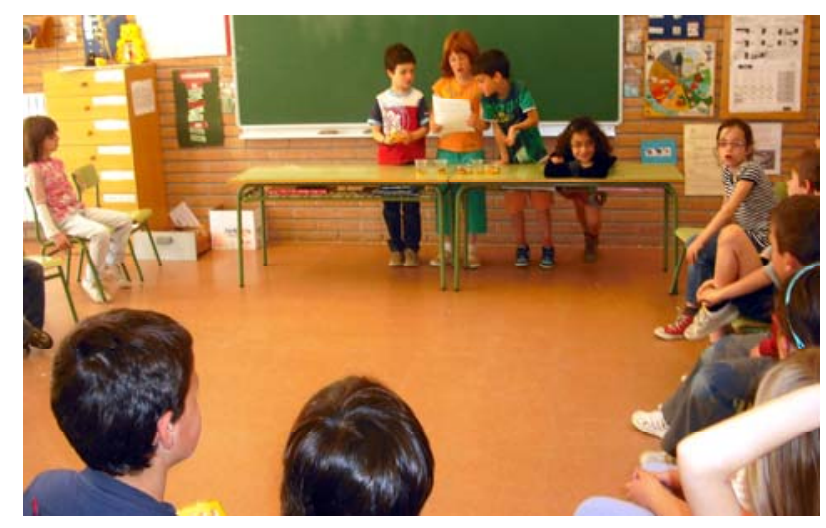

- Una eina bàsica és estimular la presa de decisions i l'autoregulació del procés que es va seguint a l'aprendre i les dificultats que van sorgint. Es fomenta en que els infants es proposin objectius, anticipin i planifiquin accions per dur-los a terme i autoregulin la seva realització, tot promovent el desenvolupament de l'autoestima de cadascun dels components del grup.

o Tot això comporta potenciar el desig de dissenyar i desenvolupar projectes propis, que tinguin en compte les capacitats i límits de cada nen o nena, i el rol que poden tenir dins del grup per construir un projecte col.lectiu.

Hem constatat que la mainada, quan treballa d'aquesta manera, va sent cada vegada més capaç de pensar, fer i comunicar per actuar de manera autònoma, solidària i responsable.

Pot semblar que aplicar aquest tipus de projectes és massa complex i difícil per fer-ho de manera regular a les nostres classes, però cal dir que una vegada s'entra en aquesta metodologia, el camí no té retorn i, a més a més, és una font de gaudi tant per al professorat com per a l'alumnat.

Tots diem: "Què bé que ens ho passem!" 


\section{Referències}

Arcà, M., Gudoni, P. i Mazzoli, P. (1990). Enseñar ciencias. Barcelona: Paidós Educador.

DeSeCo (Definition and Selection of Competentes) (2002). http://www.deseco.admin.ch/

Gardner, H. (1984). Inteligencias múltiples. Barcelona: Paidós

Garriga, N. (2009). Projectes per ajudar a evolucionar les idees científiques $i$ les competències dels infants. Llicència d'estudis concedida pel Departament d'Educació.

http://www.xtec.es/sgfp/licencies/200809/memo ries/1922m.pdf

Garriga, N. (2009). Exemples de projectes aplicats http://blocs.xtec.cat/projectesdeciencies/

Hernández, F. i Ventura, M. (1992). La organización del currículum por proyectos de trabajo. Barcelona: Ed. Graó / ICE UB.

Izquierdo, M. i Aliberas, J. (2004). Pensar, actuar $i$ parlar a la classe de ciències. Per un ensenyament de les ciències racional y raonable. Universitat Autònoma de Barcelona. Servei de Publicacions.
Jorba, J. i Caselles, E. (1996). La regulació i l'autoregulació dels aprenentatges. Bellaterra: ICE Universitat Autònoma de Barcelona. Servei de Publicacions.

Márquez, C. i Pujol, R.M. (2005). Una reflexió entorn de la conversa a les classes de ciències. Articles, 37, 31-43.

Martí J. (2006). Les idees científiques dels infants i l'ensenyament de les ciències a l'escola primària.

http://phobos.xtec.cat/cdec/images/stories/WEB antiga/recursos/pdf/primaria/idees.pdf

Martín, X. (2006). Investigar y aprender cómo organizar un proyecto. Barcelona: Editorial ICE UB-Horsori.

Pujol R.M. (2003). Didáctica de las ciencias en la educación primaria. Madrid; Síntesis Educación.

Roca, M. (2005). Les preguntes a les clases de ciències. Ciències, 2, 31-33.

Sanmartí N. (2007). Evaluar para aprender. 10 ideas clave. Barcelona: Graó.

Sanmartí, N., Burgoa, B. i Nuño, T. (2011). ¿Por qué el alumnado tiene dificultad para utilizar sus conocimientos científicos escolares en situaciones cotidianas? Alambique, 67, 62-68. 